\title{
Modeling of Multifunctional Thermoresistive Transduser Used Heat Exchange Technology
}

\author{
S. M. Osinov ${ }^{\mathrm{f}}, \mathrm{PhD}$, ORCID 0000-0003-0104-8236 \\ V. F. Zavorotnyi, PhD, ORCID 0000-0002-2240-1724 \\ B. I. Lupyna, PhD, ORCID 0000-0002-5266-308X \\ O. V. Borisov ${ }^{\mathrm{s}}$, PhD Prof., ORCID 0000-0003-4553-3591 \\ Microelectronics Department \\ National Technical University of Ukraine "Igor Sikorsky Kyiv Polytechnic Institute" \\ Kyiv, Ukraine
}

\begin{abstract}
The physical and technical characteristics, structural and topological aspects of the micromechanical thermoresistor active heating transdusers synthesis for fluid (gas and liquid) parameters determination are considered. All transducers are based on a single MEMS (Micro Electro Mechanical System) structure and differ in functionality due to different operating modes and different principles for determining fluid parameters. It allows the development of multifunctional sensors based on a single hardware, which includes a typical MEMS structure and mass production microprocessor, for example, PSoC (Programmable System On Chip). The transducers mathematical models acceptable for the COMSOL simulation library and designing of information electronics devices with the registration of various physical parameters are proposed. The analytical calculations on the basis of the proposed models for a gas flow sensor of the temperature dependence from the fluid flow velocity in the MEMS structure was performed. The proposed models can be used for the operation analytical description and computing of devices based on the use of thermoelectric processes in micro-scale structures.
\end{abstract}

Ref. 29, fig. 3.

Keywords - microelectromechanical system; thermoresistive primary transduser; thermoanemometric and conductometric measurement method

\section{INTRODUCTION}

Development of the sensing device for any physical parameter and carrying out of scientific researches with its using imply the both sensor and research field detailed elaboration [1-6]. Revealing regularities of the investigated measuring processes into the research object is solved within the problem framework. Synthesis of a new generation semiconductor submicron or nanoscale structures is mainly based on the use of laws and phenomena of solid state physics and is largely used into an empirical process. Many authors have attempted to systematize and present comprehensively such knowledge [1, 4], but the result does not create the impression of completely systematic one. The variety of phenomena and laws allowed to create a variety of semiconductor structures and devices based on them. This process has not completed but constantly develops and discovers of nanoscale effects. The variety of effects should be considered in a certain methodological manner. First of all, it concerns measured values, by means of which quantitative description of the phenomenon (effect) is given; secondly, established relationships take the form of mathematical models at certain approximation; finally the synthesis of a semiconductor device can be considered. Modern researches is hardly to imagine without the active use of software products based on basic mathematical models to formalize a process of semiconductor individual element design and a converter synthesis as a whole $[3,6]$. Such information and analytical systems with a communication interface are developed for circuit design and do not affect the design and technological constraints of particular classes of semiconductor structures. In terms of systematization of knowledge about phenomena in solids and in micromechanical thermocouples in particular, the creation of such an information system remains an urgent task, since a detailed analysis of the processes occurring in the semiconductor structure opens up possibilities for the new measuring methods implementation and the characteristics of devices improving. The systematization of knowledge in this direction can not be reduced to a formal table or a simple algorithm for defining a feature of systematization. Nowadays, there are classes of instruments for which the physical principles of functioning are presented in the form of Computer Aided Design (CAD) systems. For devices not studied or new expediency of the system approach is justified and the synthesis of the information system for the study of devices is a necessary step $[3,5,6]$. With the rapid development of Micro Electro Mechanical System (MEMS) there is a rising need for CAD. This is an unsolved part of sensing device synthesis task for the both scientific purposes and educational ones for devices based on MEMS structures using electrothermal phenomena.

There are many CAD systems that can be used to synthesize MEMS sensing structures; a detailed analysis of design tools is considered $[3,6]$. It should be noted that the authors present a point of view from the perspective of the through-design of micromechanical systems, which 
itself is a complex and global task. Existing powerful CAD systems are versatile and focused on a wide range of tasks, which sometimes makes it difficult to take into account the specific features of specific technical solutions. The feature of the synthesis of MEMS structures is a combination of technological techniques characteristic of the CMOS technology and special techniques, determined by the application area of the device and the corresponding use of physical effects. The design phases associated with the CMOS technology are usually well-studied, but the specific design steps do not have a unified representation up to date. The ones are fully relevant to MEMS structures using electrothermal phenomena [712]. The multifunctionality and closedness of individual CAD systems are not always a plus for design, especially when studying dimensional effects in MEMS. CAD systems with an open library seems preferably for such case. The possibility to use the visual system interface for the both library elements editing and new ones introducing is very important for designers; using customer's analytical equations for theire next solutions by embedded into CAD numerical methods is important too. This approach does not contradict the goal of MEMS sensor flow-through design, but rather complements it in the design of MEMS using electrothermal phenomena. The problem part of the task is both the lack of a mathematical description and how it is obtained, as well as what are the required input values and which characteristics at the synthesized model output will be determined.

However, the effectiveness of CAD systems does not solve the problem of the price of the final product the sensor, because it is determined by its mass production. Increase in mass production can be achieved by reducing the typical structures of sensors, expanding their range extension and making them multifunctional.

Having regard to mentioned, the purpose of this work is to consider the possibility of implementing a multifunctional sensor based on a typical MEMS structure and to propose basic analytical models of a thermoresistive sensor element used heat-exchange technology as a library elements for an open CAD system. The proposed models describe number of sensors based on the common sensor core (the same MEMS structure), but the physics of operation for each case was developed individually, taking into account the features of the analyzed phenomena. The proposed models can be used in open CAD systems like COMSOL to calculate and describe the operation of such sensor devices.

\section{MULTIFUNCTIONAL MICROELECTRONIC THERMORESISTIVE SENSOR}

\section{A. Application fields and technology.}

The functional dependences of the overheated by enforcement thermoresistor from environmental parameters such as temperature, pressure, fluid (gas or liquid) flow, absorbed electromagnetic power are an essential physical principle of developments $[1,4,5]$. The unified sensitive element includes a resistor assembly properly co-located either freely or at a thin-film dielectric membrane [13-15]. The membrane being made by backside through etching of a monocrystalline silicon wafer. The membrane thermal properties, geometry and on the substrate location provide a high thermal isolation of the sensitive element from the substrate and reliable contact with ambient fluid. MEMS technology is used for the such sensitive element fabrication. It mainly includes standard operation steps of microelectronic manufacturing and micromechanical engineering for many types of sensors. Atomic layer deposition technology is possible for a fabrication of the sensitive element.

Sensor signal processing circuits are individual for each type of sensor and usually include a heating power supply circuit, a measuring amplifier, an analog-to-digital (ADC) converters, heat loss and offset compensation circuits, interface electronics (lately made by IoT technology).

Fields of application of microelectronic thermal sensors are the next [2-4]:

- temperature measurement;

- fluids (gas and liquid) velocity and volume or mass flow rate measurement [15-18];

- absolute gas pressure and density measurement (including vacuum Pirani type gauges) [19-21];

- fluids (gas and liquid) composision analysis by varying heat exchange technologies;

- mechanical parameters of moving objects [22-25];

- differential pressure and velocity measurement, including infra- and low- frequency acoustic [26, 27];

- optical power measurement.

Some operational principles of such sensors are the next ones:

\section{Absolute gas pressure sensor}

The operation of the sensor is based on the internal properties of a non-stationary heated structure, including a membrane and overheated gas in the condition of unsteady heat exchange [19-21]. A bridge technique is used in which the modulated power is dissipated on the membrane and the overheating temperature amplitude relative to the matching thermoresistor is detected.

Fluid velocity, mass or volume flow rate and differential pressure sensor.

The sensor operates on a heat transfer theory for gas flowing over a micromachined overheated bridge or membrane, producing a change in the temperature profile of the membrane [15-18]. Dual sensing elements positioned at both sides of a central heating element allow for bidirectional flow measurement. The temperature difference between the sensors is transforming into a voltage signal which is in direct relation to the gas flow.

\section{Vacuum meter (Pirani type).}

The working principle of a Pirani vacuum sensor is based on the fact of a hot membrane to its ambient temperature, although the gas condition is proportional to the molecular density of the gas in the vacuum system. Our structure provides both low thermal losses through the membrane to the substrate and a large active area for 
gaseous heat conduction. A new method of ambient temperature compensation was also proposed.

\section{Gas pressure variation velocity sensor.}

The operation of the sensor is based on the inertial properties of a overheated structure including a membrane and adjacent gas in the condition of non-stationary heat exchange. A pulse current bridge technique is used, in which the incoming power is dissipated at the heater located on a membrane and detects the overheating temperature amplitude relative to the gas pressure variation.

\section{Sensor of gas density measurement.}

The principle of determining the density of gas is based on the dependence of phase characteristics of the propagation of temperature waves in the medium from the mass and concentration of molecules. The waves of temperature in gas are excited by passing an alternating electric current through one of the active resistors of the primary converter, whose construction corresponds to the base element. The following parameters of the information signal are subject to measurement: the average temperature of the gas, the frequency component of the temperature component of the oscillation, as well as the phase shift of the temperature of the primary converter relative to the phase change temperature of the heater.

\section{Bolometer.}

The detector is a resistance of a thin-film bolometer type; an adsorber radiation raises the temperature of the detector, thereby causes electrical resistance changing. This change is observed by virtue of the variation in the current bias current applied to the detector.

\section{B. Basic constructive constraints}

The presented phenomena of electrothermal transformations are basic for describing the ongoing physical processes. At this stage, it is necessary to analyze the essence of the physical phenomenon, how to describe it and what structural characteristics are basic $[1,7,9,11$, 12].

Thus, in the analysis of the gas flowmeter package according to Fig. 1 an electro-hydraulic analogy was been used. To characterize the flow forming channel, a pneumatic resistance is introduced, it is parameter that is defined as the ratio of the pressure drop $\Delta \mathrm{P}[\mathrm{Pa}]$ to the channel length $\mathrm{L}_{\mathrm{y}}$ (analogue of the voltage drop on the element) to bulk charges moving medium in the channel Q [m3 / sec] (analog of electric current):

$$
R_{h}=\lambda_{m} \lambda_{r} \frac{\Delta P}{Q}
$$

where $\lambda_{\mathrm{m}}$ - scale parameter of model, $\lambda_{\mathrm{r}}-$ dimensionless parameter of the form of the flow-forming channel cross-section, depending on the Reynolds number.

Any fluid movement in the flow-forming channel is accompanied by vortices and fluxes, especially in transition modes. If the reaction rate of the measuring system is higher than the rate of the changes in the channel, then the semiconductor structure can be treated as quasi-static. In this detail, the study of the laminar flow of the medium in the channel based on the calorimetric method is predominant.
For a cylindrical channel in a mode of laminar speed, the Reynolds number, taking into account the parameters of the medium, can be expressed through volume flow or through pressure drop $\Delta P$ on the length of the $L_{y}$ channel in accordance with the following expressions:

$$
\operatorname{Re}(Q)=\frac{4 \gamma Q}{\pi \eta D}, \quad \operatorname{Re}(\Delta P)=\frac{\gamma D^{3} \Delta P}{32 \eta^{2} L_{y}}
$$

where $\gamma\left[\mathrm{kg} / \mathrm{m}^{3}\right], \eta[\mathrm{Pa} \cdot \mathrm{s}]$ - respectively, density and kinematic viscosity of the medium in the channel.

In the worst case scenario for numbers $\operatorname{Re}<200$, the length of the channel, which provides the formation of a laminar flow, has an order of ten hydraulic diameters. Then, for channels up to $1 \mathrm{~mm}$ high, the sensing element of the transducer should be located $10 \mathrm{~mm}$ from the beginning of the channel for the implementation of the laminar mode at the upper region of the measuring range; as a result the transducer package must accordingly have dimensions of at least $20 \mathrm{~mm}$.

\section{ELECTROTHERMIC TRANSFORMATIONS IN THE THERMORESISTIVE TRANDUCERS}

Micromechanical thermistor transducers operate on the basis of electrothermal transformations, and it is envisaged to create the given temperature gradients in the thermally insulated structure (TIS) and control the heat exchange between its individual elements and the environment $[8,10]$. Structurally simple membrane, bridge or cantilever insulated TIS are multifunctional and meet the need for temperature, pressure, composition of the gas mixture, linear velocity, volume or mass flow of liquid and gas, acceleration, sound vibrations (microphones), electromagnetic radiation (bolometers) etc. The development of electronic transformer devices on their basis requires a complex statement of the problem with the obligatory consideration of both electrical and thermophysical processes directly in the TIS, as well as in the thermophysical and hydrodynamic processes in the environment fluid. Automatisation of an optimal design for such TIS and secondary converters electronic circuits development are the up to date subject of active research in the leading scientific institutions of the world.

Analysis of electrothermal processes in solid-state thermoresistive semiconductor transducers (TRST) manufactured by MEMS technology, which by their nature are substantially different from analogous processes in functional analogues created in macroscopic design.

The determination of the fluid flow velocity by methods of active heating implies either the estimation of the fraction of thermal losses of the heater into the surround flow due to its mechanical motion (thermoanemometric method) or the analysis of the change in the spatial temperature distribution into the both TIS around the heaterand the flow-forming channels (calorimetric method) $[1,7,10,11]$. The solution of the heat transfer problem in precise formulation requires finding a common solution of the following system of equations:

- Navier-Stokes equation for a non-mopping environment (equation of moments),

- equation of continuity of a flow in a channel, 
- the energy transfer equation in the filled medium channel for the temperature field $\mathrm{T}(\mathrm{x} ; \mathrm{y} ; \mathrm{z})$ in the moving flow without taking into account heat allocation due to the work performed by the forces of friction and compression,

- equation of conductive and convective heat transfer in the structural elements of the TIS taking into account heat sources geometry and heat exchange processes from the TIS' top and down surfaces.

These equations solutions require taking into account the processes occurring in the MEMS flow-forming channel; it is necessary to determine the velocities and pressures distribution for a given instant of time at any point in space. It is necessary to take into account both the initial and the boundary conditions for the completeness of the situation, depending on the type of the problem being solved. The complexity of the named equations systems prejudices a possibility of an exact solution obtaining in the general form; this is a well-known fact; therefore, different scenarios of the approximate solution are considered. There are certain solutions that establish links between the parameters of the motion of the medium and the structural elements of the semiconductor MEMS. One of such scenarios is the use of a solution in the form Gagen-Poiseuil equations.

The detailed solution by an analytical method with due consideration for simplifications described in [15] establishes links with parameters that can be influenced by manufacturing technology [16]. The common solution also is a complex task for real TRST designs. In practice, when analyzing the physical processes of measuring the transformation of the TRST, it is expedient to perform a reasonable simplification of their geometry to simple models and using of the similarity theory methods.

\section{RESULTS OF ANALITYCAL SIMULATION BY CALORIMETRIC METHOD}

The base semiconductor structure includes a membrane, a sensing element (SE) and an active heat-generating element (heater H, Fig1). It remains identical formultiple physical parameters registration, but the methods of quantitative determination of the parameter are significantly different. Simulation of electrothermal processes characteristic of structures in the MEMS design allows us to give recommendations on the geometry of the primary converter, the optimal mutual positioning of the $\mathrm{H}$ and SE, and to establish the basic characteristics of the instrument.

The simulation of processes in the structure should be considered successful if the results obtained on the basis of the both calorimetric and thermocondutometric method including:

- the study of the stationary temperature distribution in the flow-forming channel;

- the research on the heat exchange of the microbridge heat-generating element with the analysed medium in a flow-forming channel of a rectangular cross-section.

- We've took into account the specific energy exchange between the next heat exchange bodies:

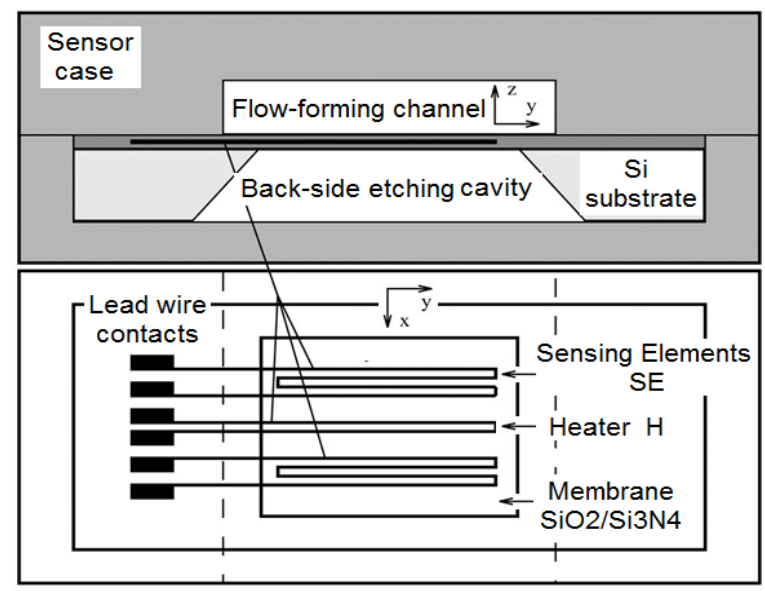

Fig. 1 The gas velocity and flow rate sensor topology.

- elements inside of the TIS;

- the roof and bottom of the flow-forming channel;

- the moving fluid into the channel.

We have analysed conductive and convective heat transfer in the typical structural elements of the TIS according to the Fig. 1 taking into account the simplified heater geometry like a beam placed on a closed dielectric membrane. We have took into account heat exchange processes from the TIS top and down surfaces into a rough approximation of liner temperature distribution towards the outer normal to TIS surfaces [15] into the both the flow-forming channel and the etching cavity. Finally we have obtained the next heat-exchange equation for TIS one-dimension temperature distribution along the flow channel:

$$
\begin{gathered}
\left(\frac{1}{2} k_{f} d_{c h}+k_{m} d_{m}\right) \frac{d^{2} T}{d y^{2}}- \\
-C_{f} \gamma_{f} d_{c h} \frac{V_{y}}{2} \frac{d T}{d y}-\left(h_{t}+h_{b}\right) T=\frac{P_{h}}{S_{h}}
\end{gathered}
$$

where $k_{f}, C_{f}, \gamma_{f}$ are the fluid heat conductivity, heat capacity and density respectively, $d_{c h}$ is the flow-forming channel height, $\mathrm{k}_{\mathrm{m}}$ and $\mathrm{d}_{\mathrm{m}}$ is the TIS supporting membrane heat conductivity and thickness, $h_{t}$ and $h_{b}$ are the TIS heat exchange coefficients from the top and bottom surface respectively, $P_{h}$ and $S_{h}$ are the heater active power and heat-exchange surface respectively.

The last equation solution gives the temperature distribution into the proposed simple model for the both flow velocity depending heater $T_{h}$ and TIS $T(y)$ towards the flowing fluid:

$$
=\frac{\begin{array}{c}
T_{h}= \\
P_{h} / S_{h}
\end{array}}{\frac{k_{f}}{d_{c h}}+\frac{k_{a i r}}{d_{b}}+S_{c h} C_{f} \gamma_{f} \frac{\sqrt{V^{2}+16 a_{f}^{2}\left(\frac{1}{2}+\frac{k_{m} d_{m}}{k_{f} d_{c h}}\right) \frac{h_{t}+h_{b}}{k_{f} d_{c h}}}}{1+2 \frac{k_{m} d_{m}}{k_{f} d_{c h}}}}
$$

where: $k_{a i r}$ is an air heat conductivity (the proposed model supposed the bottom under-TIS etching cavity filled 
by stagnant air), $a_{f}$ is fluid thermal diffusivity, $S_{c h}$ is the flow-forming channel cross-section,

$$
\begin{gathered}
\lambda=\frac{1}{4 a_{f}\left(\frac{1}{2}+\frac{k_{m} d_{m}}{k_{f} d_{c h}}\right)}\{V- \\
\left.-\sqrt{V^{2}+16 a_{f}^{2}\left(\frac{1}{2}+\frac{k_{m} d_{m}}{k_{f} d_{c h}}\right)\left(\frac{h_{t}+h_{b}}{k_{f} d_{c h}}\right)}\right\}
\end{gathered}
$$

The analytical solution takes into account the electrothermal feedback between processes in the primary and secondary transducers, allows to perform the above-mentioned studies and results the numerical estimation, specified at the Fig. 2.

\section{DIFFICULTIES IN APPLYING THE PROPOSED} APPROACH AND POSSIBLE WAYS TO OVERCOME THEM.

The outcome of the modeling presented in Section IV is the result of applying an analytical approach to solving a specific problem and for a particular model. The dependence of the temperature distribution in the membrane transducer on the flow rate of the fluid was the result of a detailed analysis and implementation of rather burdensome mathematical transformations. On the other hand, the obtained solution is a confirmation of the intuitively expected result of the physical laws of heat distribution and symmetry laws.

For obvious reasons, the analytical approach may be too complex and hard to understand in terms of interpreting the resulting final expressions after mathematical transformations and simulation results for other designs and applications of thermoresistive converters. In this case, it is advisable to use a more general mathematical approach for describing the behavior of elements of thermoresistive converters able to become a communicative language for the user of system design.

In the general case it is necessary to implement an approach that will describe the behavior of processes and synthesize new applications based on thermoresistive converters, and in this case, it is necessary to solve the differential equation of the form $[15,16]$. The solution to this problem can be due to various reasons, for example, the solution of algebraic equations derived from the differential equation for $\mathrm{t} \rightarrow \infty$, finding the maximum and minimum solutions in the time interval, studying the nature of the transient process in time for the subject of stability, etc. The peculiarity of this task is that the engineer is interested in the solution at the end of a considerable time, this is important for practical tasks, that is, it is necessary to establish the nature of the changes of the solution, will it be constant or have a oscillation character.

To solve the equation, it is proposed to apply the method of finite differences and implement it with the use of the principle of quasi-analogy, which is used in electronic modeling. In doing so, we note that in our study there is no need to create a proper electronic model and the technical implementation of the achievement of equivalence conditions is not considered. Perspective use of the algorithm of transition from differential equation to finite differences and from them to the electrical analogue of the finite-difference equation. Such an approach can be used for the CAD synthesis of the system of thermoresistive converters for two reasons: 1) due to the developed numerical methods for solving systems of algebraic equations; 2) the typical problem is considered and the transition to the electrical analogy of the finite-difference equation does not cause difficulties and as a result actually we obtain a system of algebraic equations, and the procedure for their synthesis is reduced to the use of simple and understandable rules and the process can be easily automated.

Thus, in the case of significant complications in the application of the analytical approach to solving a particular problem and for a particular model, as a possible alternative, it is proposed to use a modified finite-difference method for modeling elements of thermoresistive converters.

\section{SIMULATION TO OPTIMIZE THE MULTIFUNCTIONAL DESIGN OF THE MICROELECTRONIC THERMORESISTIVE SENSOR}

The expansion of the capabilities of a multifunctional microelectronic thermosetting sensor occurs due to certain changes in its operating modes. The higher mentioned sensor of the gas density measurement, which is intended to determine the specific gravity of hydrocarbons in the control systems of the combustion process, the systems for monitoring natural gas leaks, etc., is given as an example.

The physical principles of the measurement process are described in detail in $[20,21]$. It should be noted that an increase in the concentration of molecules in volume on the thermal conductivity may not occur, since with the increase in specific heat capacity simultaneously the length of free run of molecules decreases. This leads to the fact that the dependence of the thermal conductivity on the density in certain ranges of densities and temperatures can have an extremum, that is, it is ambiguous. Essentially, there is a requirement for the coexistence of the geometric dimensions of the primary converter with the free path of the molecule in the working ranges of concentrations. In addition, it is necessary to take into account the very significant damping of the amplitude of the temperature fluctuations in the medium in accordance with the following coordinate-time dependence $T(x, t)$ for the model of the thermal wave penetration into the semispace [28]:

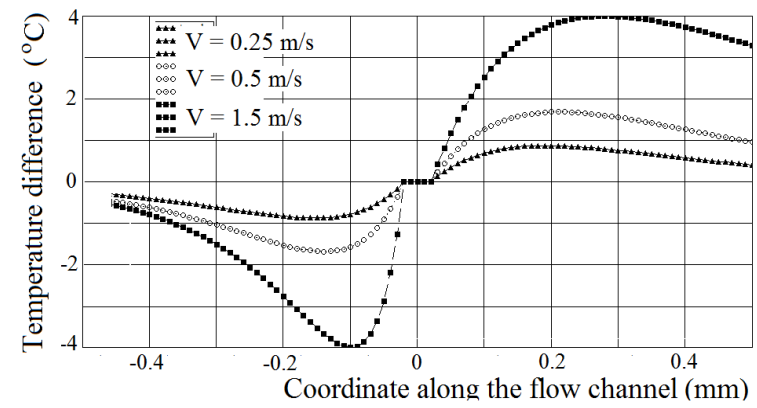

Fig. 2. Calculated dependence of temperature change in the membrane plane on the linear air velocity into a fluid-forming channel. 


$$
T(x, t)=T_{0} \exp \left(-\sqrt{\frac{\omega}{2 a}} x\right) \cos \left(\omega t-\sqrt{\frac{\omega}{2 a}} x\right)(6),
$$

where $T_{0}$ is the amplitude of the temperature fluctuations of the heater, $\omega$ is the frequency of temperature fluctuations, $\mathrm{a}$ is the thermodiffusivity, $\mathrm{t}$ is the time, $\mathrm{x}$ is the coordinate in the normal to the half-space boundary.

The simulation of the thermal wave penetration into the medium gives a substantially expressed maximum in the spatial dependence of the variation of the temperature fluctuation amplitude on the coordinate when the thermal diffusivity is changed. Fig. 3 shows the corresponding curves, the analysis of which confirms the optimal use of measuring transducers in the MEMS performance with their characteristic dimensions of the order of tens hundreds of microns and their own constant time of about a few milliseconds. The dependence of the relative change in the amplitude of the temperature fluctuation (vertical axis) from the distance $\mathrm{x}$ from the boundary as a result of the change in the temperature diffusivity from a1 $=2 \cdot 10^{-5}\left[\mathrm{~m}^{2} / \mathrm{sec}\right]$ (air under normal conditions) to $\mathrm{a} 05=10^{-5}\left[\mathrm{~m}^{2} / \mathrm{sec}\right]$ for the frequencies $\omega 1=100 \mathrm{~Hz}, \omega 2$ $=50 \mathrm{~Hz}, \omega 3=10 \mathrm{~Hz}$ clearly shows the presence of the optimal spatial location of the heater and the registering temperature converter for the analysis of the characteristics of the medium over the temperature diffusivity and the derivatives of its thermal conductivity, specific heat and density. A feature is the curve narrowing and the resulting expected increase in criticality to the geometric optimization of the converter with increasing operating frequency.

The implementation of the method for measuring the density of gases occurs by determining the heat exchange between the heating element of the converter and the gas, provided that the electric current is transmitted in periodic mode according to the harmonic law. The two parameters of the alternating signal are subject to measurement: the phase shift of the temperature of the gas at a distance $\mathrm{d}$ from the heater relative to the phase of the temperature variation of the heating element and the frequency of oscillation, as well as the temperature of the gas. Then the density is determined by the equation [21]:

$$
\rho=A \frac{\sqrt{T}}{\omega}\left(\frac{\Delta \varphi}{d}\right)^{2}
$$

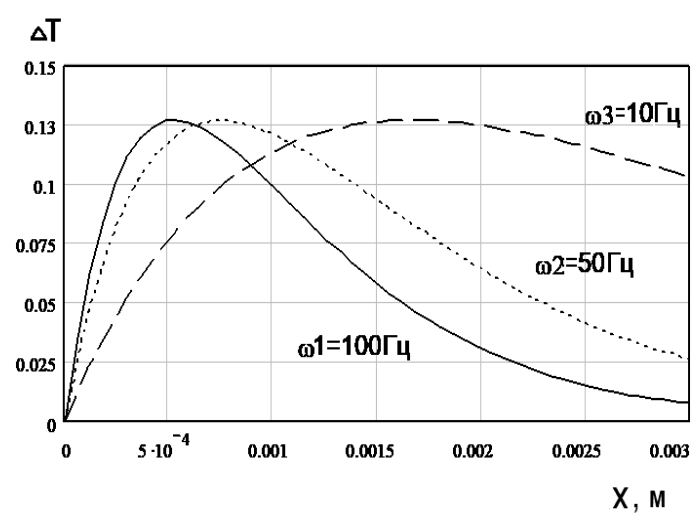

Fig. 3 The simulated dependence of the relative change in the amplitude of the temperature fluctuation $\Delta \mathrm{T}$ upon penetration of the thermal wave in the fluid at a depth $\mathrm{x}$ as a result of a thermodiffusivity change. where $T$ is the gas temperature, $\Delta \varphi$ is the phase shift of the temperature fluctuations at a distance $d$ from the heater, $A$ is the constant which is determined experimentally during the calibration. The constructive parameter of the converter $\mathrm{d}$ must be determined with reference to the working values of the density of the medium and be optimized in accordance with the results shown in Fig. 3.

Calculations for the sensor model described above show that the conversion characteristic is not symmetrical. This result requires an appropriate asymmetrical arrangement of the sensors relative to the heater. For the bidirectional measurement of the linear velocity and the simultaneous preservation of the maximum sensitivity of the method, a matrix of sensitive elements will be required.

\section{VERIFICATION OF THE MODEL AND SIMULATION}

The adequacy of the proposed advanced model is confirmed by the correspondence of the calculated data obtained in the work with the results of experimental studies of similar structures performed by the authors in previous works $[20,29]$ and in the works of other authors $[10,16]$.

Primary differential pressure transducer UR3201NR01-1 for measuring range from $10^{-2}$ to $1.510^{+3} \mathrm{PA}$, the advanced mathematical model of which is considered above in this work, was produced serially in accordance with TU U24571552.001-99. This transducer was used in devices of diagnostics of the external respiration function of the person "Pulmovent". Absolute error of measurement of volumetric flow in the range from 0.1 to $1.5 \mathrm{l} / \mathrm{s}$ was not more than $\pm 0.045 \mathrm{l} / \mathrm{s}$ and limits of permissible relative error in the measurement of volumetric flow in the measurement range from 1,5 to $15,01 / \mathrm{s}$ was not more than $\pm 3 \%$

\section{CONCLUSIONS}

All considered transducers are based on a single MEMS structure and differ in functionality due to different operating modes and different principles for determining fluid parameters. It allows the development of multifunctional sensors based on a single hardware, which includes a typical MEMS structure and mass production microprocessor, for example, PSoC.

The mathematical model which is accepted as the basis for synthesis of the library and designing of information electronics devices with the registration of various physical parameters is proposed.

The analytical calculation on the basis of the proposed model for a gas flow sensor of the temperature dependence from the fluid flow velocity in the MEMS structure was performed.

The result obtained is the basis for the implementation of a perspective design of a multifunctional thermosetting sensor for the two-way registration of gas flow rates.

The proposed models can be used in open systems like COMSOL for the calculation and description of the operation of devices based on the use of thermoelectric processes in small-sized structures. 
ACKNOWLEDGMENTS

This research was supported by the Laboratory of Medical Sensors, the Microelectronics Department of National Technical University of Ukraine "Kyiv Polytechnic Institute named Igor Sikorsky" in part research work 0117U005112 "Dynamic processes in integral devices of the information electronics".

\section{REFERENCES}

[1] N. Damean and P. P. L. Regtien, "Measurement concepts: From classical transducers to new MEMS," Meas. J. Int. Meas. Confed., vol. 27 , no. 3 , pp. $159-178,2000$, DOI: $10.1016 / \mathrm{S} 0263-$ 2241(99)00057-3.

[2] Girnyak Y., "Microelectronic Mechanical Systems In Modern Equipment," Meas. Equip. Metrol., no. 69, pp. 97-102, 2008.

[3] V.M. Tesliuk, Models and Information Technologies for the Synthesis of Microelectromechanical Systems. Lviv: Tower and Co, 2008.

[4] M. Hautefeuille, B. O'Flynn, F. H. Peters, and C. O'Mahony, "Development of a microelectromechanical system (MEMS) Based multisensor platform for environmental monitoring," Micromachines, vol. 2, no. 4, pp. 410-430, 2011, DOI: 10.3390/mi2040410.

[5] S. Seok, Handbook of Mems for Wireless and Mobile Applications. Woodhead Publishing Limited, 2013, ISBN: 9780857092717

[6] I.Sh. Nevlyudov, V.V. Evseev, V.O. Bortnikova, Ya.O. Zamirets, "Analysis of modern means of automated design of microelectromechanical systems," Technol. Adm., no. 1, pp. 3-8, 2014.

[7] N. Damean, P. P. L. Regtien, and M. Elwenspoek, "Heat transfer in a MEMS for microfluidics," Sensors Actuators A Phys., vol. 105 , no. 2 , pp. 137-149, Jul. 2003, DOI: 10.1016/S09244247(03)00100-6.

[8] G. Kozlov, D. Randjelovich, Z. Djurić, "Analytical Modeling of Transient Processes in Thermal Microsensors," in 12th. Int. Conf. Thermal, Mechanical and Multiphysics Simulation and Experiments in Microelectronics and Microsystems, EuroSimE, 2011, pp. $1-7$.

[9] Feuchter M., "Investigations on Joule heating applications by multiphysical continuum simulations in nanoscale systems", $\mathrm{PhD}$ Disser. Karlsruher Institut fur Technologie (KIT), 2014, ISBN: 978-3-7315-0261-6.

[10] A.G. Kozlov, "Error and adequacy of analytical modeling of temperature distribution in thermal microsystems," in Problems of the development of promising micro and nanoelectronic systems 2014, Collected., 2014, pp. 167-172.

[11] T. S. J. Lammerink, N. R. Tas, G. J. M. Krijnen, and M. Elwenspoek, "A new class of thermal flow sensors using $\Delta \mathrm{T}=0$ as a control signal," in Proceedings IEEE Thirteenth Annual International Conference on Micro Electro Mechanical Systems (Cat. No.00CH36308), pp. 525-530, DOI: 10.1109/MEMSYS.2000.838572.

[12] K. Kliche, S. Billat, F. Hedrich, C. Ziegler, and R. Zengerle, "Sensor for gas analysis based on thermal conductivity, specific heat capacity and thermal diffusivity," in 2011 IEEE 24th International Conference on Micro Electro Mechanical Systems, 2011, pp. 1189-1192, DOI: 10.1109/MEMSYS.2011.5734644.

[13] B. Zheng, C. Zhou, Q. Wang, Y. Chen, and W. Xue, "Deposition of Low Stress Silicon Nitride Thin Film and Its Application in Надійшла до редакції 16 березня 2019 р.
Surface Micromachining Device Structures," Adv. Mater. Sci. Eng., vol. 2013, pp. 1-4, 2013, DOI: 10.1155/2013/835942.

[14] Lupyna B.I., "Micromechanical surface thermo-resistor transducer of linear fluid velocity in a rectangular cross-section channel," Electron. Commun., vol. 21, no. 3(92), pp. 17-28, 2016. DOI: $10.20535 / 2312-1807.2016 .21 .3 .81454$

[15] Patent of Ukrane No 76885 "A method for manufacturing a matrix of thermoresistive converters," 2, 2013.

[16] N. T. Nguyen and W. Dötzel, "Asymmetrical locations of heaters and sensors relative to each other using heater arrays: a novel method for designing multi-range electrocaloric mass-flow sensors," Sensors Actuators A Phys., vol. 62, no. 1-3, pp. 506512, Jul. 1997, DOI: 10.1016/S0924-4247(97)01529-X.

[17] A. Talic, S. Cerimovic, R. Beigelbeck, F. Kohl, T. Sauter, and F. Keplinger, "MEMS Flow Sensors Based on Self-Heated aGeThermistors in a Wheatstone Bridge," Sensors, vol. 15, no. 5, pp. 10004-10025, Apr. 2015, DOI: 10.3390/s150510004.

[18] J. W. Van Honschoten, G. J. M. Krijnen, V. B. Svetovoy, H. E. De Bree, and M. C. Elwenspoek, "Analytic model of a two-wire thermal sensor for flow and sound measurements," $J$. Micromechanics Microengineering, vol. 14, no. 11, pp. 1468 1477, 2004, DOI: $10.1088 / 0960-1317 / 14 / 11 / 006$.

[19] G.A.Frolov, O.M.Grudin, I.I.Katsan, B.I.Lupina "Micromechanical gas heat capasity sensor," in ESSDERS 96 , 26th European Solid State Device Research Conference, 1996, pp. 215-218.

[20] O. M. Grudin, G. A. Frolov, I. I. Katsan, and B. I. Lupina, "Thermal microsensor with a.c. Heating for gas-pressure measurements," Sensors Actuators, A Phys., vol. 62, no. 1-3, pp. 571-575, 1997, DOI: $10.1016 /$ S0924-4247(97)01571-9.

[21] V.F. Zavorotny, O.V. Borisov, B.I.Lupina, S.M.Osinov. Patent of Ukraine No 18749 "Method of determination of gas density," 2006.

[22] F. Mailly, H. B. Nguyen, L. Latorre, and P. Nouet, "CMOS implementation of a 3 -axis thermal convective accelerometer," Proc. IEEE Sensors, vol. 2014-December, no. December, pp. 1471-1474, 2014, DOI: 10.1109/ICSENS.2014.6985292.

[23] J. Bahari, R. Feng, and A. M. Leung, "Robust MEMS Gyroscope Based on Thermal Principles," J. Microelectromechanical Syst., vol. 23, no. 1, pp. 100-116, Feb. 2014, DOI: 10.1109/JMEMS.2013.2262584.

[24] S. Liu and R. Zhu, "Micromachined Fluid Inertial Sensors," Sensors, vol. 17, no. 2, p. 367, Feb. 2017, DOI: $\underline{10.3390 / \mathrm{s} 17020367}$

[25] I.Sh. Nevlyudov, V. Bortnikova. "Methods of automated design of manufacturing processes of MEMS accelerometers," Technol. Approv. Dev., no. 1, pp. 8-10, 2018.

[26] D. Yntema, "An integrated three-dimensional sound-intensity probe. Ph.D. Thesis," University of Twente, Enschede, The Netherlands, 2008.

[27] O. Pjetri, "Two - Dimentional Acoustic Particle Velocity Sensors Based on a Crossing Wires Topology, PhD Thesis," University of Twente, Enschede, The Netherlands, 2016.

[28] Sivukhin D.V., The general course of physics. Thermodynamics and molecular physics. Moscow: Nauka, 1979.

[29] O.V.Borisov, I.S.Deineca, B.I.Lupyna. "Measurement of dynamic parameters of micromechanical thermistor converter using NI Elvis II software and hardware," Electron. Commun., no. 5 (64), pp. 5-12, 2011. 
УдК 621.383

\title{
Моделювання багатофункціанального терморезистивного перетворювача, що використовує технологію теплообміну
}

\author{
Осінов ${ }^{f}$ C. M., к.T.H., ORCID 0000-0003-0104-8236 \\ Заворотний В. Ф., к.фіз.-мат.н., ORCID 0000-0002-2240-1724 \\ Лупина Б. I., к.т.н., ORCID 0000-0002-5266-308X \\ Борисов ${ }^{\mathrm{s}}$ О. В., к.т.н. проф., ORCID 0000-0003-4553-3591 \\ Кафедра мікроелектроніки \\ Національний технічний університет України \\ «Київський політехнічний інститут імені Ігоря Сікорського» \\ Київ, Україна
}

\begin{abstract}
Анотація-У роботі проведено аналіз електронних, теплових і гідродинамічних фізичних процесів, характерних для структур первинних перетворювачів, виготовлених за технологією кремнісвої мікроелектромеханіки. Розглянуто фізико-технічні характеристики, структурні та топологічні аспекти функціонування мікромеханічних терморезисторних теплоізольованих структур активного нагрівання, які можуть бути основою для синтезу бібліотеки елементів первинних перетворювачів в системах автоматизованого проектування пристроїв інформаційної електроніки. Особливістю уніфікованої теплоізольованої структури є її багатофункціональність, що надає можливість на базі єдиного модельного підходу до функціонування терморезисторного первинного перетворювача активного нагрівання розробити низку сенсорів фізичних величин: абсолютного та диференційного тиску газового середовища, лінійної швидкості та масових витрат флюїду, потужності електромагнітного випромінювання тощо. Всі перетворювачі засновані на сдиній структурі MEMS (Micro Electro Mechanical System) і відрізняються за функціональністю за рахунок різних режимів роботи і різних принципів визначення параметрів рідини. Це дозволяє розробляти багатофункціональні датчики на основі сдиного обладнання, що включає в себе типову структуру МЕМС i мікропроцесор масового виробництва, наприклад, PSoC (Programmable System On Chip). B роботі розвинено запропоновану авторами в попередніх роботах математичну модель поверхневого терморезисторного первинного перетворювача лінійної швидкості потоку на діелектричній мембрані, вмонтованого в стінку потокоформуючого каналу прямокутного поперечного перерізу. Проведено поглиблений аналіз теплообмінних процесів між елементами теплоізольованої структури, оточуючим флюїдом і елементами корпусу. В запропонованій моделі реальної структури первинного перетворювача враховано геометричні і теплофізичні параметри мембрани, потокоформуючого каналу, геометрії теплоізоюючої порожнини травлення кремнію. Отримано рівняння, яке описус такі процеси в квазістатичному наближенні, наведено його розв'язок, виконано чисельний розрахунок залежності профілю температури теплоізольованої структури від швидкості потоку рідини в потокоформуючому каналі. Наведений в роботі аналітичний розв'язок надає можливість оптимізації чутливості первинного перетворювача до лінійної швидкості потоку флюїду в каналі та його вимірювального діапазону з врахуванням параметрів геометрії теплоізольованої структури і каналу. Запропонована модель може бути використаною у відкритих системах автоматизованого проектування типу COMSOL для розрахунку конструкції та аналізу фізичних засад функціонування пристроїв на основі теплоізольованих резисторних структур активного нагрівання з використання теплообмінних процесів у конструкціях міліметрових, мікронних та субмікронних розмірів..
\end{abstract}

Бібл. 29, рис.3

Ключові слова - мікроелектромеханічна система; терморезистивний первинний перетворювач; термоанемометричний і кондуктометричний метод вимірювання. 


\title{
Моделирование многофункционального терморезистивного преобразователя, использующего технологию теплообмена.
}

Осинов ${ }^{\mathrm{f}}$ C. H., к.T.H., ORCID 0000-0003-0104-8236

Заворотный В. Ф., к.физ.-мат.н., ORCID 0000-0002-2240-1724

Лупина Б. И., к.т.н., ORCID 0000-0002-5266-308X

Борисов ${ }^{\text {s }}$ А. В., к.т.н. проф., ORCID 0000-0003-4553-3591

Кафедра микроэлектроники

Национальный технический университет Украины

«Киевский политехнический институт имени Игоря Сикорского»

Киев, Украина

\begin{abstract}
Аннотация-В работе рассмотрена систематизация электронных, тепловых и гидродинамических физических моделей, характерных для процессов в структурах первичных преобразователей, изготовленных по технологии кремниевой микроелектромеханикы. Рассмотрены физико-технические характеристики, структурные и топологические аспекты синтеза микромеханических терморезисторов активного нагрева для определения параметров среды (газа и жидкости). Предложена математическая модель, которая является основой для синтеза библиотеки элементов системы САПР и проектирования устройств информационной электроники для регистрации различных физических параметров. Проведен аналитический расчет температурной зависимости от скорости потока жидкости в структуре МЭМС на основе предложенной модели для датчика газового потока. Предложенные модели могут быть использованы в открытых системах САПР типа COMSOL для расчета и описания работы устройств на основе использования термоэлектрических процессов в малогабаритных конструкциях.
\end{abstract}

Библ. 29, рис.3

Ключевые слова - микроэлектромеханическая система; терморезистивный первичный преобразователь; термоанемометрические и кондуктометрический метод измерения 